\title{
Assessment of Conjugate Complexes of Chitosan and Urtica dioica or Equisetum arvense Extracts for the Control of Grapevine Trunk Pathogens
}

\author{
Natalia Langa-Lomba ${ }^{1,2}$, Laura Buzón-Durán ${ }^{3}$, Pablo Martín-Ramos ${ }^{1}{ }^{\mathbb{D}}$, José Casanova-Gascón ${ }^{1, *}$ (i), \\ Jesús Martín-Gil ${ }^{3}{ }^{\circledR}$, Eva Sánchez-Hernández ${ }^{3}$ and Vicente González-García ${ }^{2}$ \\ 1 Instituto Universitario de Investigación en Ciencias Ambientales de Aragón (IUCA), EPS, Universidad de \\ Zaragoza, Carretera de Cuarte s/n, 22071 Huesca, Spain; natalialangalomba@gmail.com (N.L.-L.); \\ pmr@unizar.es (P.M.-R.) \\ 2 Plant Protection Unit, Agrifood Research and Technology Centre of Aragón, Instituto Agroalimentario de \\ Aragón-IA2 (CITA-Universidad de Zaragoza), Avda. Montañana 930, 50059 Zaragoza, Spain; \\ vgonzalezg@aragon.es \\ 3 Department of Agricultural and Forestry Engineering, ETSIIAA, Universidad de Valladolid, Avenida de \\ Madrid 44, 34004 Palencia, Spain; laura.buzon@uva.es (L.B.-D.); mgil@iaf.uva.es (J.M.-G.); \\ eva.sanchez.hernandez@uva.es (E.S.-H.) \\ * Correspondence: jcasan@unizar.es; Tel.: +34-9742-39339
}

check for updates

Citation: Langa-Lomba, N.;

Buzón-Durán, L.; Martín-Ramos, P. Casanova-Gascón, J.; Martín-Gil, J.; Sánchez-Hernández, E.;

González-García, V. Assessment of Conjugate Complexes of Chitosan and Urtica dioica or Equisetum arvense Extracts for the Control of Grapevine Trunk Pathogens. Agronomy 2021, 11, 976. https://doi.org/10.3390/ agronomy11050976

Academic Editors: Beatriz Gámiz and Essaid Ait Barka

Received: 27 March 2021

Accepted: 12 May 2021

Published: 14 May 2021

Publisher's Note: MDPI stays neutral with regard to jurisdictional claims in published maps and institutional affiliations.

Copyright: (c) 2021 by the authors. Licensee MDPI, Basel, Switzerland. This article is an open access article distributed under the terms and conditions of the Creative Commons Attribution (CC BY) license (https:// creativecommons.org/licenses/by/ $4.0 /)$
Abstract: In the work presented herein, we analyze the efficacy of three basic substances that comply with European Regulation (EC) No 1107/2009, namely chitosan, horsetail (Equisetum arvense L.) and nettle (Urtica dioica L.), for the control of grapevine trunk diseases (GTDs) in organic farming. The E. arvense and $U$. dioica aqueous extracts, prepared according to SANCO/12386/2013 and SANTE/11809/2016, have been studied by gas chromatography-mass spectrometry (GC-MS), identifying their main active constituents. The three basic substances, either alone or in combination (forming conjugate complexes), have been tested in vitro against eight Botryosphaeriaceae species, and in vivo, in grafted plants artificially inoculated with Neofusicoccum parvum and Diplodia seriata. A clear synergistic behavior between chitosan and the two plant extracts has been observed in the mycelial growth inhibition tests (resulting in $\mathrm{EC}_{90}$ values as low as $208 \mu \mathrm{g} \cdot \mathrm{mL}^{-1}$ for some of the isolates), and statistically significant differences have been found in terms of vascular necroses lengths between treated and non-treated plants, providing further evidence of aforementioned synergism in the case of $D$. seriata. The reported data supports the possibility of extending the applications of these three basic substances in Viticulture beyond the treatment of mildew.

Keywords: basic substances; Botryosphaeriaceae; chitosan; fungicide; GTDs; horsetail; nettle; Vitis vinifera

\section{Introduction}

Phytofungicides are receiving increasing attention as an alternative to synthetic fungicides for the management of many fungal plant diseases [1,2], due to their advantages in terms of safety, easy biodegradability, environmental friendliness and low toxicity.

In the European Union, some of the active substances allowed in organic production (viz. bio-sourced and traditional botanical extracts, light supports / aids and plant defense enhancers), have been approved as 'basic substances' under the EU plant protection products regulation (Article 23 of (EC) No 1107/2009) [3]. These basic substances are listed in Part C of the Annex to Regulation 540/2011, and include Equisetum arvense L., chitosan hydrochloride, Urtica spp., Salix spp. cortex, mustard seeds powder and Allium cepa L. bulb extract, among others.

Chitosan exhibits antimicrobial properties, but also functions as an elicitor, stimulating natural defense mechanisms [4]. The accepted and potential mechanisms of action behind its antimicrobial properties are thoroughly discussed in the review paper by $\mathrm{Ma}$, et al. [5]. 
According to SANCO/12388/2013, it can be used in water solution for application on various crops, including 'fruit berries and small fruit'.

Horsetail (E. arvense) was the first approved basic substance, in 2014. A complex mixture of biologically-active carbohydrates [6], flavonoids [7] and antioxidants [8] can be obtained from its dried aerial parts. Silicic, tartaric, protocatechuic and caffeic acids, as well as apigenin, kaempferol and isoquercitrin have been found in its extracts [9-11]. Horsetail can be used in accordance with SANCO/12386/2013. In the particular case of Vitis vinifera L., discussed in this work, Appendix II includes its use as a fungicide for the control of downy (Plasmopara viticola (Berk. \& M.A.Curtis) Berl. \& De Toni) and powdery (Erysiphe necator (Schwein.) Burrill) mildews by foliar application, but extensions of its use against other fungal diseases on vegetable crops and horticulture are being analyzed [12].

More recently, Commission Implementing Regulation (EU) 2017/419 approved Urtica spp. as a basic substance. Its biological activity has been referred to its content in acetic, chlorogenic and formic acids, rutin, lecithin and L-prunasin [13]. Review report SANTE/11809/2016 contemplates its use in grapevine to control downy mildew by foliar spraying.

Regarding the applicability of these three basic substances as natural antifungal products for crop-protection, that of chitosan is well-established, as discussed in a recent review by Mukhtar Ahmed, et al. [14]. There are also studies on the antimicrobial properties of extracts from E. arvense [15,16] and other Equisetum spp. [10,17-19], and Urtica spp. extracts [20-24].

Nonetheless, to the best of the authors' knowledge, while chitosan has been tested against grapevine trunk diseases (GTDs) in various studies [25-27], the other two basic substances have not (the application of $E$. arvense extracts against fungal pathogens in relation to grapevine has been limited to assays against $P$. viticola [28] and ochratoxigenic moulds [29]). Taking into consideration that an enhanced antifungal activity generally results from the formation of conjugate complexes between chitosan and other substances of natural origin [30-32], and that the legal framework would place no obstacles to a combined use of already approved basic substances, this possibility deserves to be explored, since it can be instrumental in controlling GTDs, which are among the main challenges facing modern Viticulture [33].

Even though some of GTDs-associated problems have been described for at least a century, from the 1990s there has been a notable advance in unraveling the etiology and epidemiology of a series of complex syndromes first collectively known as grapevine esca [34]. Despite the numerous advances made in the generation of knowledge about this type of pathologies, in the last 25-30 years the incidence and economic losses in the sector due to these mycoses have not stopped increasing [35]. At present, it is commonly accepted that there are several factors that are influencing the advance of this type of phytopathological problems in the vineyard, highlighting above all the changes in cultural practices, the prohibition of certain fungicidal substances and the high demand for propagation material. Concerning current approaches employed to prevent and control these pathologies, Mondello, et al. [33] summarized, in an extensive revision, the different trials and strategies assayed in the last 25 years to find and make available to the market different GTD control strategies, based on a wide-range of organic and inorganic compounds, both synthetic and natural, and on biocontrol agents (BCAs). Some of these approaches have included natural compounds, just in the same way as the ones assayed in the present work.

The aim of the study presented herein has been to explore the effectiveness of aforementioned three basic substances and their conjugate complexes against certain GTDs, with a view to providing scientific evidence to support their extension to other applications in Viticulture beyond the treatment of diseases that affect the green organs. 


\section{Materials and Methods}

\subsection{Fungal Isolates}

The eight fungal isolates employed in the study represented some of the main Botryosphaeriaceae taxa associated with the so-called Botryosphaeria dieback/Black Dead Arm disease in Spain (Table 1) and were supplied as lyophilized vials (later reconstituted and refreshed as PDA subcultures) by the Agricultural Technological Institute of Castilla and Leon (ITACYL, Valladolid, Spain).

Table 1. Fungal isolates used in the study.

\begin{tabular}{|c|c|c|c|c|}
\hline Code & Isolate & Binomial Nomenclature & Geographical Origin & Host/Date \\
\hline ITACYL_F098 & Y-084-01-01a & Diplodia seriata De Not. & $\begin{array}{l}\text { Spain } \\
\text { (DO Toro) }\end{array}$ & $\begin{array}{c}\text { Grapevine } \\
\text { (Tempranillo) } \\
2004\end{array}$ \\
\hline ITACYL_F111 & Y-091-03-01c & $\begin{array}{c}\text { Neofusicoccum parvum (Pennycook \& } \\
\text { Samuels) Crous, Slippers \& } \\
\text { A.J.L.Phillips }\end{array}$ & $\begin{array}{c}\text { Spain } \\
\text { (Navarra, nursery) }\end{array}$ & $\begin{array}{c}\text { Grapevine (Verdejo) } \\
2006\end{array}$ \\
\hline ITACYL_F141 & Y-127-02-01 & $\begin{array}{c}\text { Botryosphaeria dothidea (Moug.) Ces. \& } \\
\text { De Not. }\end{array}$ & $\begin{array}{l}\text { Spain } \\
\text { (Galicia) }\end{array}$ & $\begin{array}{l}\text { Grapevine } \\
2005\end{array}$ \\
\hline ITACYL_F066 & T-046-05-3B & $\begin{array}{c}\text { Dothiorella iberica A.J.L.Phillips, } \\
\text { J.Luque \& A.Alves }\end{array}$ & Spain & $\begin{array}{l}\text { Grapevine } \\
\text { (Tempranillo) } \\
2009\end{array}$ \\
\hline ITACYL_F187 & Y-291-24-01 & Diplodia coryli Fuckel & $\begin{array}{c}\text { Spain } \\
\text { (Gordoncillo, León) }\end{array}$ & $\begin{array}{l}\text { Grapevine (Prieto } \\
\text { Picudo) } \\
2010\end{array}$ \\
\hline ITACYL_F081 & Y-051-04-03a & $\begin{array}{l}\text { Dothiorella sarmentorum (Fr.) } \\
\text { A.J.L.Phillips, A.Alves \& J.Luque }\end{array}$ & $\begin{array}{c}\text { Spain } \\
\text { (DO Tierra de León) }\end{array}$ & $\begin{array}{l}\text { Grapevine (Prieto } \\
\text { Picudo) } \\
2004\end{array}$ \\
\hline ITACYL_F118 & Y-103-08-01 & $\begin{array}{c}\text { Dothiorella viticola A.J.L.Phillips \& } \\
\text { J.Luque }\end{array}$ & $\begin{array}{c}\text { Spain } \\
\text { (Extremadura) }\end{array}$ & $\begin{array}{l}\text { Grapevine } \\
2004\end{array}$ \\
\hline ITACYL_F080 & Y-050-05-01c & Diplodia mutila (Fr.) Mont. & $\begin{array}{c}\text { Spain } \\
\text { (DO Ribera de Duero) }\end{array}$ & $\begin{array}{l}\text { Grapevine } \\
2004\end{array}$ \\
\hline
\end{tabular}

\subsection{Reagents and Preparation of Chitosan Oligomers and Bioactive Formulations}

Chitosan (CAS 9012-76-4; high MW: 310,000-375,000 Da) was supplied by Hangzhou Simit Chem. \& Tech. Co. (Hangzhou, China). Citric acid (CAS 77-92-9), sodium alginate (CAS 9005-38-3) and calcium carbonate (CAS 471-34-1) were purchased from Sigma-Aldrich Química (Madrid, Spain). Neutrase ${ }^{\mathrm{TM}} 0.8 \mathrm{~L}$ enzyme was supplied by Novozymes A/S (Bagsværd, Denmark). Potato dextrose agar (PDA) was purchased from Becton Dickinson (Bergen County, NJ, USA). For the preparation of the E. arvense and $U$. dioica extracts, European Pharmacopoeia certified dry plants were purchased from El Antiguo Herbolario (Alicante, Spain).

Chitosan oligomers (COS) were prepared according to the procedure previously reported in [31]. The obtaining of the E. arvense and $U$. dioica extracts was conducted according to Appendix I in SANCO/12386/2013 and SANTE/11809/2016, respectively. In short, horsetail extract was obtained by water decoction: $200 \mathrm{~g}$ of dry plant were macerated in $10 \mathrm{~L}$ of water for $30 \mathrm{~min}$ (soaking) and then boiled for $45 \mathrm{~min}$. After cooling down, the decoction was filtrated and further diluted 10-fold with water, to obtain a final concentration of $2000 \mu \mathrm{g} / \mathrm{mL}$. In the case of nettle extract, dry nettle leaves $(15 \mathrm{~g} / \mathrm{L})$ were macerated 3 to 4 days at $20^{\circ} \mathrm{C}$, followed by filtering and dilution of the filtrate to obtain a final concentration of $2000 \mu \mathrm{g} / \mathrm{mL}$.

The COS-nettle extract and COS-horsetail extract complexes were obtained by mixing of the respective solutions in a 1:1 $(v / v)$ ratio. The mixture was then sonicated for $15 \mathrm{~min}$ in five 3-min pulses (so that the temperature did not exceed $60{ }^{\circ} \mathrm{C}$ ) using a probe-type ultrasonicator (model UIP1000hdT; Hielscher Ultrasonics, Teltow, Germany; 1000 W, 20 kHz). 
Infrared spectroscopy was used to confirm the formation of the conjugate complexes (see supporting information).

\subsection{Horsetail and Nettle Extracts Characterization}

Taking into consideration that materials of plant origin are usually characterized by a high variability of phytochemical composition, resulting from both genetic and environmental variability (due to the influence of weather and soil fertility on the content of active substances), and that extraction procedures also influence the content of bioactive compounds, the aqueous plant extracts were characterized by gas chromatography-mass spectrometry (GC-MS) at the Research Support Services (STI) at Universidad de Alicante (Alicante, Spain). A gas chromatograph model 7890A coupled to a quadrupole mass spectrometer model 5975C (both from Agilent Technologies, Santa Clara, CA, USA) was used. The chromatographic conditions were: injection volume $=1 \mu \mathrm{L}$; injector temperature $=280{ }^{\circ} \mathrm{C}$, in splitless mode; initial oven temperature $=60^{\circ} \mathrm{C}, 2 \mathrm{~min}$, followed by ramp of $10^{\circ} \mathrm{C} / \mathrm{min}$ up to a final temperature of $300^{\circ} \mathrm{C}, 15 \mathrm{~min}$. The chromatographic column used for the separation of the compounds was an Agilent Technologies HP-5MS UI of $30 \mathrm{~m}$ length, $0.250 \mathrm{~mm}$ diameter and $0.25 \mu \mathrm{m}$ film. The mass spectrometer conditions were: temperature of the electron impact source of the mass spectrometer $=230{ }^{\circ} \mathrm{C}$ and of the quadrupole $=150{ }^{\circ} \mathrm{C}$; ionization energy $=70 \mathrm{eV}$. NIST11 library was used for compound identification.

\subsection{In Vitro Tests of Mycelial Growth Inhibition}

The fungicidal potential of the different compounds was determined employing an agar dilution method [36]; briefly, aliquots of stock solutions of each product combination were incorporated onto the PDA medium to concentrations in the $62.5-1500 \mu \mathrm{g} \cdot \mathrm{mL}^{-1}$ range. Then, mycelial plugs (5 $\mathrm{mm}$ in diam.) of each pathogen coming from the margin of 7-day-old PDA cultures were transferred to plates incorporating the above-mentioned concentrations for each compound ( 3 plates per treatment/concentration, with 2 replicates) and incubated for 6 days (in the case of $N$. parvum and D. seriata) or 7 days (for the other six fungi) at $25{ }^{\circ} \mathrm{C}$ in the dark, which was the amount of time needed for the isolates to the reach the Petri dish border in the control plates (which consisted of PDA medium without any amendment). Thus, a total of 2400 plates were scored and analyzed as a result of having tested five treatments (COS, E. arvense extract, $U$. dioica extract, COS- $E$. arvense conjugate complex and COS- $U$. dioica conjugate complex) at 10 concentrations per treatment against eight fungal pathogens.

Mycelial growth rates were determined by calculating the average diameter of 2 perpendicular colony axes for each replicate. Growth inhibition of each treatment and concentration was calculated and compared with controls at the end of the incubating period according to the formula:

$$
\left(\left(d_{\mathrm{c}}-d_{\mathrm{t}}\right)\right) / d_{\mathrm{c}} \times 100
$$

where $d_{\mathrm{c}}$ and $d_{\mathrm{t}}$ represent the average diameters of the fungal colony of the control and the treated fungal colony, respectively.

Results were also expressed as both $\mathrm{EC}_{50}$ and $\mathrm{EC}_{90}$ effective concentrations, estimated by means of PROBIT analysis in R statistical software [37].

\subsection{Greenhouse Bioassays in Grafted Plants}

Together with the experiments of mycelial growth inhibition in vitro, bioassays with the mentioned basic substances and their conjugate complexes (which comply with EU regulation) were performed in living young grapevine plants in order to scale the protective capabilities of these compounds against two Botryosphaeriaceae species responsible for grapevine trunk diseases (GTDs). Neofusicoccum parvum and D. seriata were then selected on the basis of their prevalence/frequency of isolation in Spain and adjacent areas [38], especially in young grapevine plants coming from nurseries [39]. In summary, potted plants were artificially infected with the two mentioned pathogens, treated simultane- 
ously with the different conjugate complexes and, finally, protection effects were analyzed from the comparison of the vascular lesions produced after the different treatments tested with the different controls. Briefly, plant material consisted of 47 plants each of cultivars "Tempranillo" (CL. 32 clone) (2-years old) and "Garnacha" (VCR3 clone) (one year old) grafted on 775P and 110R rootstocks, respectively. Plants were grown on 3.5 L plastic pots containing a mixed substrate of moss peat and sterilized natural soil (75:25), incorporating slow release fertilizer when needed. Plants were maintained in the greenhouse with drip irrigation and anti-weed ground cover for six months (June-December 2020). One week after placing them in the greenhouse, grapevine plants were inoculated with the mentioned two Botryosphaeriaceae taxa together with either COS, COS-nettle or COS-horsetail treatments simultaneously. Five repetitions were arranged for each pathogen/control product and plant combination (cultivar/rootstock), together with 4 positive controls per pathogen and cultivar plus 3 negative controls (incorporating only the bioactive product) for each treatment (Table S1). Inoculations of both pathogens and control products were carried out directly on the trunk of the living plants at two sites per plant stand (separated a minimum of $5 \mathrm{~cm}$ among them) below the grafting point and not reaching the root crown. For the pathogens, agar plugs coming from 5-days-old fresh PDA cultures of each species were used as fungal inoculum. In the mentioned two inoculation points of each grapevine plant, slits (made up with a scalpel) of approx. $3 \mathrm{~mm}$ in diameter and $0.5 \mathrm{~cm}$ deep were done. After this, $0.5 \mathrm{~cm}$ diameter agar plugs were inoculated and placed in such a way that the mycelium was in contact with vascular tissue in the stem. Calcium alginate beads served as dispersal matrix, including the different control products and conjugates assayed, and beads were placed at both sides of the agar plug. For this, beads were prepared as follows; each control product was added to a 3\% sodium alginate solution in a 2:8 ratio (20 mL compound/80 mL sodium alginate). Then, this solution was dispensed drop by drop onto a $3 \%$ calcium carbonate solution to spherify (polymerize) in beads of $0.4-0.6 \mathrm{~cm}$ diameter containing the different control treatments. Finally, both agar plugs and beads were covered with cotton soaked in sterile bi-distilled water and sealed with Parafilm ${ }^{\mathrm{TM}}$ tape. During the assay period, application of copper (cuprous oxide $75 \%$, Cobre Nordox ${ }^{\mathrm{TM}}$ 75 WG) to control downy mildew outbreaks was performed in mid-July, together with a first sprouting (followed by periodic sprouting). Grapevine plants were visually examined weekly during the whole assay period for the presence foliar symptoms including both inter-nerval and nerval necroses. After six months in the greenhouse, plants were removed and two sections of the inoculated stems between the grafting point and the root crown were prepared, sectioned longitudinally and the length of the vascular necroses (tracheomycosis) caused by the different pathogens evaluated. Thus, the length of the vascular necroses was measured longitudinally on upper and lower directions from the inoculation point for both halves of the longitudinal cut, and the average measures of these statistically analyzed and compared depending on the type of pathogen and product formulation employed. All the data were compared with controls. Finally, grapevine plants removed and measured at the end of the assay were also processed to re-isolate the different pathogenic taxa previously inoculated. Thus, in order to fulfill Koch's postulates, $0.5 \mathrm{~cm}$ long wood chips exhibiting vascular necroses $(1-2 \mathrm{~cm}$ around the wounds) were washed, surface sterilized, placed in PDA plates amended with streptomycin sulphate (to prevent bacterial contamination) and incubated at $26{ }^{\circ} \mathrm{C}$ in the dark in a culture chamber for 2-3 days.

\subsection{Statistical Analyses}

Data obtained in the in vitro mycelial growth inhibition tests were assessed by analysis of variance (ANOVA) followed by post hoc comparison of means through Tukey's test at $p<0.05$ (provided that the homogeneity and homoscedasticity requirements were satisfied, according to the Shapiro-Wilk and Levene tests). In the case of greenhouse assay results, since the normality and homoscedasticity requirements were not met, the 
Kruskal-Wallis non-parametric test was used instead, with Conover-Iman test for post hoc multiple pairwise comparisons. R statistical software was used [37].

\section{Results}

\subsection{Horsetail and Nettle Extracts}

The spectra of the aqueous extracts for the two plant species are presented in Figure 1.

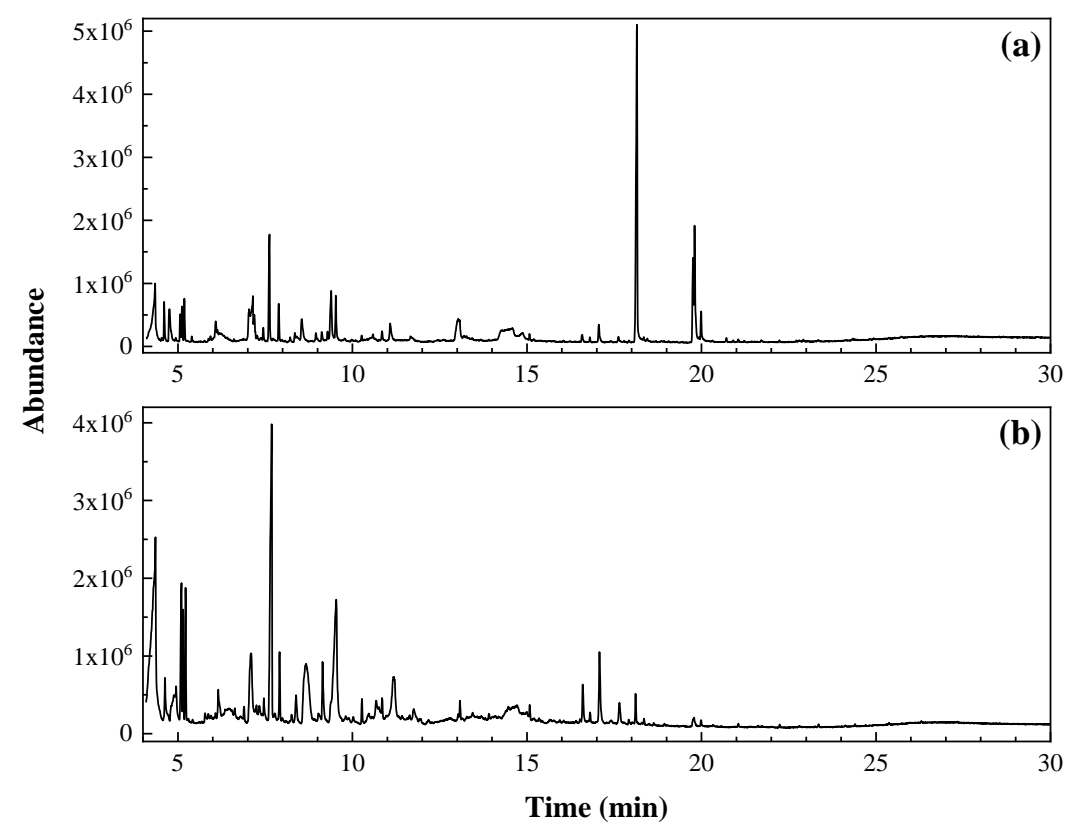

Figure 1. GC/MS spectra of (a) E. arvense and (b) U. dioica aqueous extracts.

The main constituents of E. arvense aqueous extract were: $n$-hexadecanoic acid or palmitic acid $(18.3 \%)$, 2-furanmethanol or $\alpha$-furylcarbinol $(9.1 \%)$, oleic acid $(5.9 \%)$, cyclopropyl carbinol (5.0\%), 1,6-anhydro- $\beta$-D-glucopyranose or levoglucosan $(4.1 \%)$, 4-oxo-pentanoic acid or levulinic acid (3.9\%), 1-bromo-7-(tetrahydro-2-pyranyloxy)heptane (3.8\%), (Z,Z)-9,12-octadecadienoic acid or cis-linoleic acid (3.7\%), 3-deoxy-d-mannoic lactone $(3.6 \%)$, dihydroxyacetone $(2.8 \%)$, 2-ethyl-5-methyl-tetrahydrofuran $(2.7 \%)$, 5-hydroxymethylfurfural (2.3\%) and dihydro-4-hydroxy-2(3H)-furanone $(2.2 \%)$.

Regarding $U$. dioica aqueous extract, the main phytoconstituents were found to be: 2-furanmethanol (16.7\%), N-methyl-1,3-propanediamine (10.1\%), thiazole (8.9\%), dihydro4-hydroxy-2(3H)-furanone (6.4\%), tetrahydro-2H-pyran-2-methanol (4.1\%), 4,5-dihydro2-methyl-1H-imidazole (2.9\%), (S)-2-hydroxy-2-methyl-butanedioic acid or L-citramalic acid $(2.3 \%), 3-$ deoxy-d-mannoic lactone (2.2\%), 2-hydroxy-2-cyclopenten-1-one $(2.0 \%)$ and $\mathrm{N}$-[2-(4-morpholinyl)ethyl]- $\alpha$-oxo-1H-indole-3-acetamide $(2.0 \%)$.

A more detailed analysis of their chemical composition is presented in Tables S2 and S3, together with a comparison with other phytochemical analyses reported in the literature for the extracts from these two plants.

\subsection{In Vitro Efficacy}

Fungal growth tests for E. arvense and $U$. dioica extracts-alone (data not shown) led to very low inhibition percentages (below $25 \%$ in all cases). More promising results of growth inhibition were observed in tests employing treatments based on COS, either alone or in combination with the plant aqueous extracts (Figure 2, Figures S3-S5). In these tests, it was observed that, concerning the amount of bioactive compound, the higher the dosage assayed, the higher the growth inhibition obtained for all treatments, with significant differences among concentrations. Together with this, a synergistic effect was observed when conjugate complexes were employed instead of the stand-alone basic substances: while full inhibition was observed for all pathogens for COS at a concentration of 
$1500 \mu \mathrm{g} \cdot \mathrm{mL}^{-1}$ (except for D. mutila, for which full inhibition was reached at $1000 \mu \mathrm{g} \cdot \mathrm{mL}^{-1}$ ), complete fungal growth inhibition was attained at noticeably lower concentrations (ranging from 250 to $1500 \mu \mathrm{g} \cdot \mathrm{mL}^{-1}$, depending on the treatment and isolate) for the COSplant extracts conjugate complexes. Moreover, the results showed that pathogens such as $D$. viticola or D. mutila were much more sensitive to the action of the conjugate complexes than the rest of the species tested: for these two taxa, noticeable reductions in mycelial growth were detected at doses of around $250 \mu \mathrm{g} \cdot \mathrm{mL}^{-1}$. On the other hand, differences were also observed in the ability to control fungal growth between the two types of conjugates, at least for some of the pathogens: species such as D. iberica or $D$. coryli were found to be more sensitive to the action of the COS-E. arvense conjugate than to the COS-U. dioica treatment, both in terms of the level of reduction of growth rates at the same concentrations and in terms of the lethal dose.
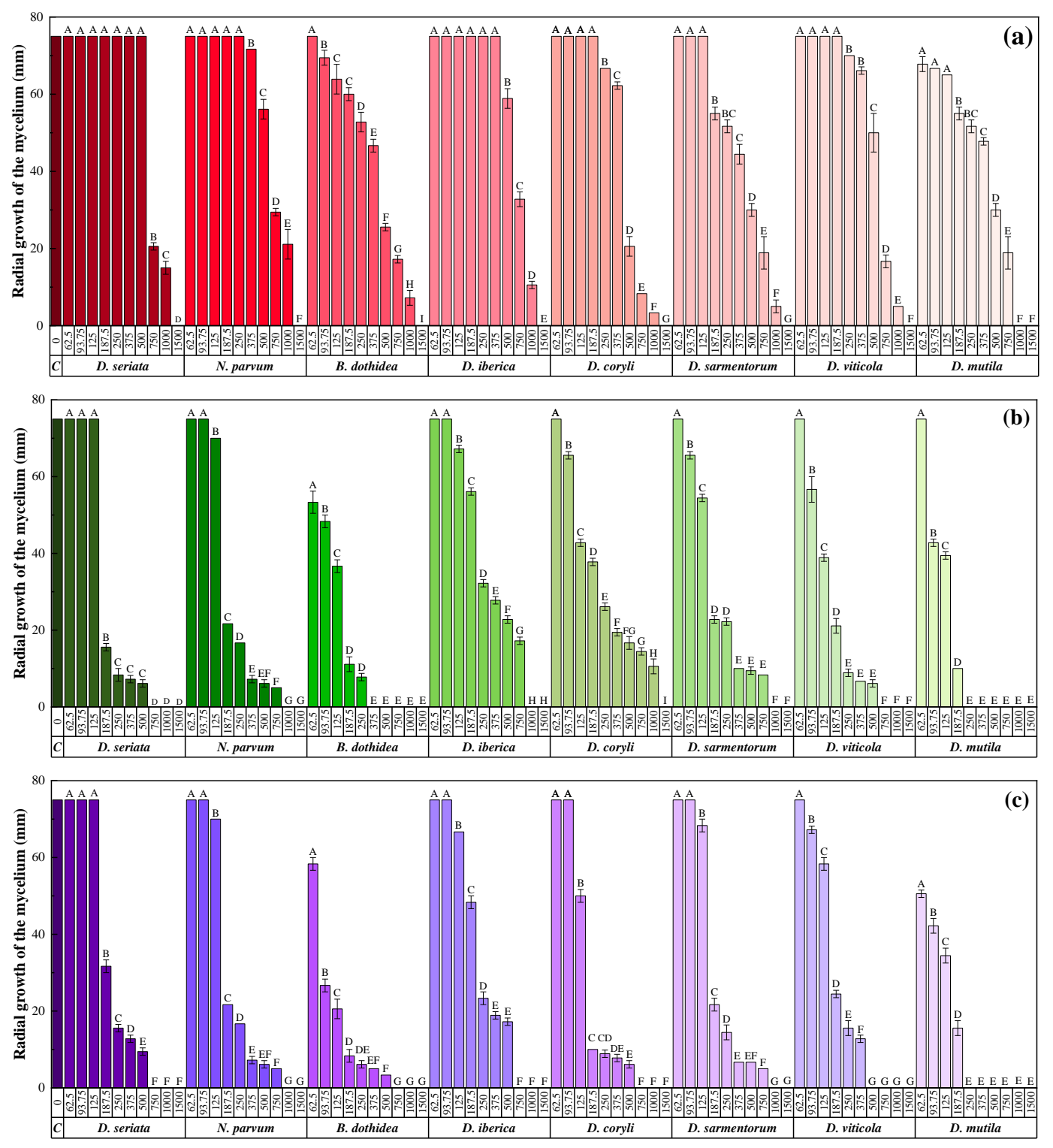

Figure 2. Radial growth of the mycelium for the eight Botryosphaeriaceae species under study obtained in in vitro tests conducted in PDA medium with different concentrations $\left(62.5,93.75,125,187.5,250,375,500,750,1000 \mathrm{and} 1500 \mu \mathrm{g} \cdot \mathrm{mL}^{-1}\right)$ of: (a) chitosan oligomers (COS); (b) COS-U. dioica extracts conjugate complex; and (c) COS-E. arvense extracts conjugate complex. The same letters above concentrations mean that they are not significantly different at $p<0.05$. Error bars represent standard deviations. ' $\mathrm{C}$ ' in the leftmost column refers to the control (PDA-only, without any amendment) plates. Only one control plate is plotted for the sake of readability, although there was one control plate per isolate (as shown in the bottom row of Figures S3-S5). 
To facilitate comparisons between treatments, the effective in vitro concentrations are summarized in Table 2 (effective concentrations for the E. arvense and U. dioica extracts alone are not presented, provided that — as mentioned above-full inhibition was not attained even at the highest assayed concentration, so a reliable fitting could not be obtained). In line with the observations made upon comparison of the series of compound dosages (Figure 2), a clear synergistic effect was observed for the two COS-plant extract conjugate complexes in all cases, except for D. coryli, in which the $\mathrm{EC}_{90}$ for COS alone was lower than that of COS-E. arvense formulation. The efficacy for the COS-horsetail and COS-nettle extract treatments were similar in most cases (except against $D$. coryli, in which the performance of COS-nettle extract was noticeably better).

Table 2. $\mathrm{EC}_{50}$ and $\mathrm{EC}_{90}$ effective concentrations for the different treatments, expressed in $\mu \mathrm{g} \cdot \mathrm{mL}^{-1}$.

\begin{tabular}{|c|c|c|c|c|c|c|c|c|c|}
\hline Treatment & & D. seriata & N. parvum & B. dothidea & D. iberica & D. coryli & D. sarmentorum & D. viticola & D. mutila \\
\hline \multirow{2}{*}{$\cos$} & $\mathrm{EC}_{50}$ & 744.4 & 680.2 & 362.8 & 706.6 & 472.2 & 398.7 & 554.3 & 343.7 \\
\hline & $\mathrm{EC}_{90}$ & 1179.9 & 1326.6 & 1191.6 & 1196.4 & 972.4 & 1075.9 & 1138.7 & 1196.8 \\
\hline \multirow{2}{*}{ COS-E. arvense } & $\mathrm{EC}_{50}$ & 173.9 & 214.1 & 109.4 & 304.1 & 155.3 & 198.2 & 148.2 & 118.6 \\
\hline & $\mathrm{EC}_{90}$ & 429.0 & 637.1 & 267.1 & 817.3 & 999.0 & 669.0 & 351.1 & 208.3 \\
\hline \multirow{2}{*}{ COS-U. dioica } & $\mathrm{EC}_{50}$ & 211.5 & 215.2 & 72.6 & 253.0 & 162.9 & 203.0 & 175.3 & 100.3 \\
\hline & $\mathrm{EC}_{90}$ & 483.5 & 650.2 & 334.4 & 625.8 & 411.6 & 533.0 & 379.7 & 227.1 \\
\hline
\end{tabular}

\subsection{In Planta Assays}

Statistically significant differences were found in terms of the lengths of the vascular necroses between treated and non-treated plants for both fungal pathogens. In addition, visual comparison of the lengths observed after sectioning grapevine plants between treated plants and controls (those plants inoculated only with the pathogens or with the control products, respectively) corroborated statistical results (Figure 3). As regards differences among treatments, in the case of $N$. parvum the performance of the three assayed formulations (and unlike what was observed in in vitro tests) was found to be similar (Table 3), while in the case of $D$. seriata the synergistic behavior observed in the in vitro tests was evidenced (Table 4), with a higher efficacy of the treatments based on conjugate complexes than that of COS alone, which was not significantly different from the control. It was also observed that, in general terms, treatments based on conjugate complexes were slightly more effective when used against $D$. seriata.

Table 3. Kruskal-Wallis test and multiple pairwise comparisons using the Conover-Iman procedure for the lengths of the vascular necroses for N. parvum.

\begin{tabular}{|c|c|c|c|c|c|c|}
\hline Sample & Frequency & Sum of Ranks & Mean of Ranks & & Groups & \\
\hline COS negative control & 48 & 3366.000 & 70.125 & A & & \\
\hline COS-U. dioica negative control & 48 & 3458.500 & 72.052 & A & & \\
\hline COS-E. arvense negative control & 40 & 3444.500 & 86.113 & A & & \\
\hline COS-E. arvense & 64 & 15017.000 & 234.641 & & B & \\
\hline COS-U. dioica & 72 & 17119.500 & 237.771 & & B & \\
\hline cos & 64 & 16600.000 & 259.375 & & B & \\
\hline Positive control & 64 & 21194.500 & 331.164 & & & C \\
\hline
\end{tabular}



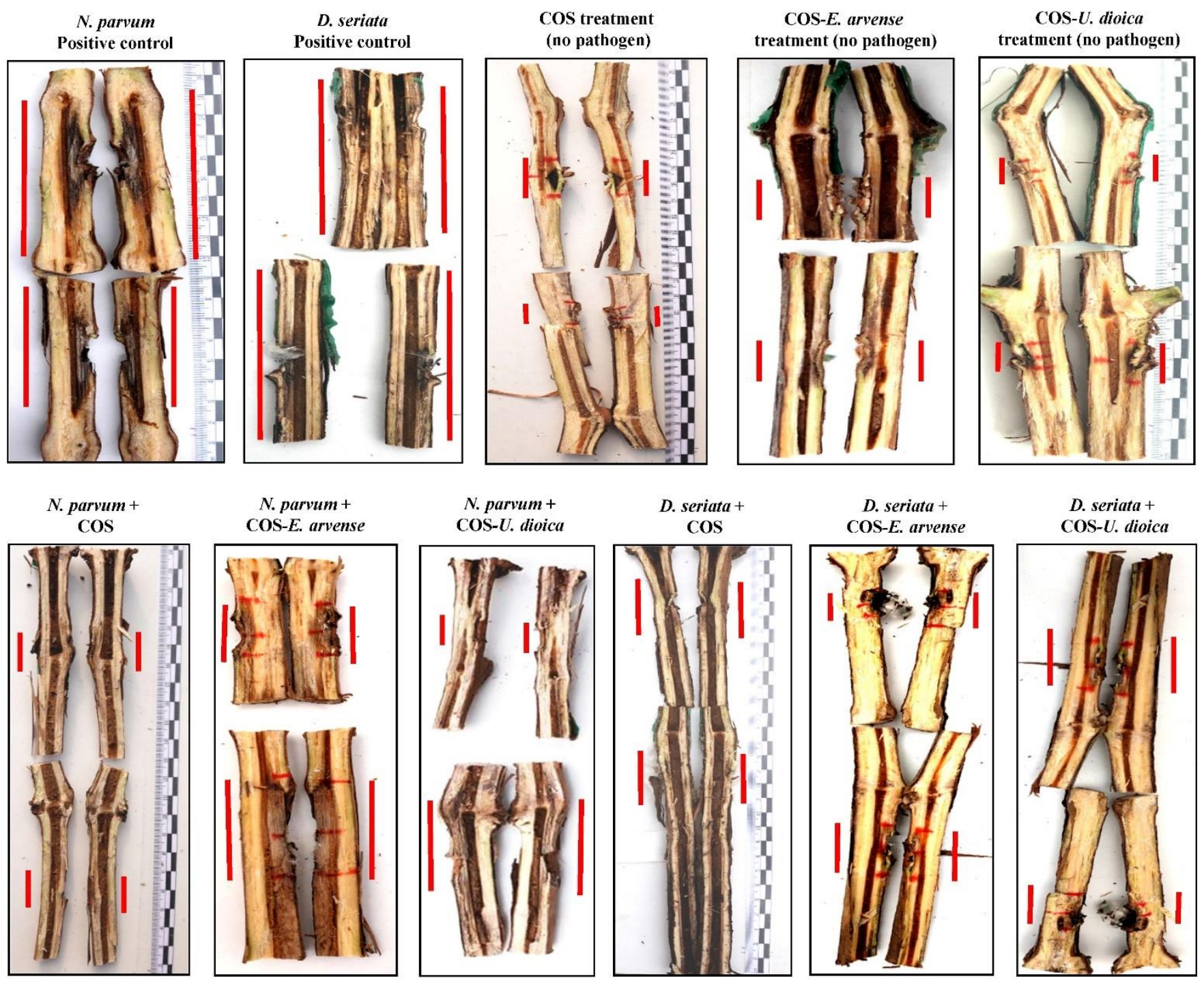

Figure 3. Vascular necroses observed after removal and sectioning of grapevine plants artificially inoculated with both pathogens and control products. Top row, from left to right: vascular necroses produced by N. parvum, D. seriata, COS treatment, COS-E. arvense extract and COS-U. dioica extract; Bottom row, from left to right: vascular necroses produced by N. parvum + COS, N. parvum + COS-E. arvense extract, N. parvum + COS-U. dioica extract, D. seriata + COS, $D$. seriata + COS-E. arvense extrat and D. seriata + COS-U. dioica extract, respectively. Red lines delimit the extent of lesions.

Table 4. Kruskal-Wallis test and multiple pairwise comparisons using the Conover-Iman procedure for the lengths of the vascular necroses for $D$. seriata.

\begin{tabular}{|c|c|c|c|c|c|c|}
\hline Sample & Frequency & Sum of Ranks & Mean of Ranks & & Groups & \\
\hline COS-U. dioica negative control & 48 & 4216.500 & 87.844 & A & & \\
\hline COS negative control & 48 & 4255.000 & 88.646 & $\mathrm{~A}$ & & \\
\hline COS-E. arvense negative control & 40 & 4504.500 & 112.613 & A & & \\
\hline COS-E. arvense & 80 & 16097.000 & 201.213 & & B & \\
\hline COS-U. dioica & 80 & 18098.500 & 226.231 & & B & \\
\hline $\cos$ & 64 & 20311.000 & 317.359 & & & $\mathrm{C}$ \\
\hline Positive control & 56 & 19253.500 & 343.813 & & & $\mathrm{C}$ \\
\hline
\end{tabular}




\section{Discussion}

\subsection{Efficacy Comparisons}

Regarding chitosan oligosaccharides-based treatments, Cobos, et al. [25] found a complete inhibition of D. seriata and B. dothidea at $1000 \mu \mathrm{g} \cdot \mathrm{mL}^{-1}$; and $\mathrm{EC}_{90}$ values in the 967-1270 $\mu \mathrm{g} \cdot \mathrm{mL}^{-1}$ range for $N$. parvum, in the $1121-1360 \mu \mathrm{g} \cdot \mathrm{mL}^{-1}$ range for D. seriata and of $1339 \mu \mathrm{g} \cdot \mathrm{mL}^{-1}$ for B. dothidea were obtained for the same strains in [30,31] (vs. 1326, $1180,1192 \mu \mathrm{g} \cdot \mathrm{mL}^{-1}$ in this work, respectively). Differences in the inhibitory concentrations may be ascribed to the existence of different isolate-dependent susceptibility profiles or to slight variances in the molecular weight or deacetylation degree of COS, which influence its efficacy.

In connection with $E$. arvense and $U$. dioica extracts, a summary of their effectiveness against various polyphagous phytopathogenic fungi (Phytophthora infestans, Fusarium spp., Aspergillus spp., Alternaria spp., etc.), including grapevine pathogens (Botrytis cinerea, Plasmopara viticola) and wood decay fungi (Phanerochaete chrysosporium, Ceriporiopsis subvermisphora, Gloeophyllum trabeum, Trametes versicolor, Oligoporus placenta, Pleurotus ostreatus and Coniophora puteana) is presented in Table S4. It is worth noting that, although $100 \%$ inhibition has been attained against some fungal pathogens by using concentrations of E. arvense extract of $3 \%[40,41]$ and of $U$. dioica extract of $0.9 \%$ [23], such concentrations exceed the limit allowed by the European Union $(0.2 \%)$. In the studies in which this latter concentration was tested, the inhibition was moderate: for instance, for E. arvense extract, La Torre, et al. [28] reported a $32.4 \%$ effectiveness against $P$. viticola, and Sen and Yalcin [24] found inhibitions of $25 \%$ against P. chrysosporium, G. trabeum, P. ostreatus and C. puteana for $U$. dioica extracts. These results are comparable to the inhibition found in the present study $(<25 \%)$.

Concerning COS-based conjugate complexes, $\mathrm{EC}_{90}$ values of 507.5, 580.2 and $497.4 \mu \mathrm{g} \cdot \mathrm{mL}^{-1}$ were obtained in previous studies for N. parvum, D. seriata and $B$. dothidea, respectively, with a COS- $\varepsilon$-polylysine conjugate [31]. When COS-tyrosine conjugate was used instead, $\mathrm{EC}_{90}$ values of $1021.4,672.1$ and $707.7 \mu \mathrm{g} \cdot \mathrm{mL}^{-1}$, respectively, were reported [30]. For the COS-E. arvense extract and COS-U. dioica extract conjugates discussed herein, $\mathrm{EC}_{90}$ values of $637-650,429-483$ and $267-334 \mu \mathrm{g} \cdot \mathrm{mL}^{-1}$ were registered.

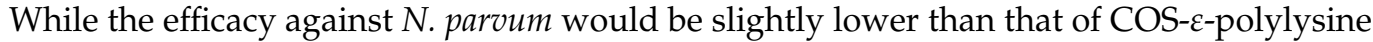
conjugate complex, those against $D$. seriata and $B$. dothidea would be higher, with the additional advantage of using legally-accepted basic substances.

As regards a comparison with the $\mathrm{EC}_{50}$ values of technical-grade commercial fungicides (Table S5), the values obtained for the conjugate complexes (173.9-211.5, 214.1-215.2, 72.6-109.4 and $100.3-118.6 \mu \mathrm{g} \cdot \mathrm{mL}^{-1}$ against D. seriata, N. parvum, B. dothidea and D. mutila, respectively) would be in the same order of magnitude of the less effective conventional fungicides (e.g., boscalid, metalaxyl or copper oxychloride), but would exhibit a substantially lower effectiveness than fungicides such as flusilazole, tebuconazole, carbendazim or fludioxonil.

With respect to plant bioassays, comparisons of lengths of vascular necroses measured after the application of the different treatments (COS alone and conjugate complexes) showed that, regardless the pathogen considered, the average lengths of necroses were reduced with the different treatments and that these lengths were statistically different from both those produced in control plants inoculated only with the pathogens and from lesions observed when only control products were incorporated to the artificial wounds (Tables 3 and 4). Visual estimations of this protective effect can be also observed in Figure 3: vascular necroses were clearly lower in treated plants (for the three treatments), at both sides of inoculation points, in comparison with positive controls. In this sense, the statistical analyses indicated that the application of control products in the absence of any pathogen produced very low values of vascular discoloration length, which were similar in the three compounds, probably due to a hypersensitivity reaction restricted to the area occupied by the artificially inflicted wounds (Figure 3). In general terms, the median lengths of vascular necrosis obtained after the application of the control products in the case of $N$. parvum were further away from the values recorded in the case of $D$. seriata. Moreover, the treatment of this latter pathogen with COS did not result in a significant 
reduction of vascular necrosis, being in the same range as the pathogen control. The control of these two and other Botryosphaeriaceae taxa has been extensively studied in vine plants through the use of fungicidal substances, biocontrol agents or natural products. Rusin, et al. [42], in a study on the control of Lasiodiplodia theobromae employing a combined set of BCAs, synthetic fungicides and natural products, found different protection levels depending on the product applied, but in the case of plant extracts (garlic and clove), these authors obtained average length values higher than those obtained with the assayed synthetic fungicides and BCAs. Amponsah, et al. [43] evaluated the sensitivity of certain Botryosphaeriaceae taxa (N. luteum, N. australe and D. mutila) against several technicalgrade commercial fungicides in potted grapevines treated with chemicals, and reported dieback lesion lengths for N. luteum noticeably lower than the ones obtained in our study. Other studies on the control of these botryosphaeriaceous fungi dealing with BCAs [44] or conventional fungicides [45] have shown that, with some exceptions, the degree of protection tends to be higher when conventional fungicidal substances are used instead of microbial antagonists.

\subsection{Mechanism of Action}

Liu, et al. [46] suggested that fatty acids might be applicable to the integrated control of phytopathogens. They tested fatty acids against Alternaria solani, Fusarium oxysporum f. sp. cucumerinum, F. oxysporum f. sp. lycopersici and Colletotrichum lagenarium, finding that they had an inhibitory effect both on the mycelial growth and spore germination. The extent of inhibition varied depending upon both the type of fatty acids and the fungal species tested. They concluded that saturated fatty acids, i.e., palmitic acid (found in E. arvense extract at high concentrations, see above), showed stronger antifungal activity than unsaturated fatty acids. The main molecular mechanism by which fatty acids are thought to act is through their direct insertion into the fungal plasma membrane, resulting in increased fluidity, deregulation of membrane proteins and altered hydrostatic turgor pressure within the cell, leading to cytoplasmic disorder and ultimately to cell death [47]. According to Pohl, et al. [48], palmitic acid should result in an enhanced antifungal efficiency, which has been demonstrated against Aspergillus niger, A. terreus and Emericella nidulans by Altieri, et al. [49].

With regard to other active substances present in E. arvense, dihydroxyacetone (Figure S2) has been reported to exhibit fungicidal activity in medical contexts [50], and 3-deoxy-d-mannoic lactone (present, for instance, in garlic) also has antimicrobial activity [51].

Concerning carbinols, it is recognized that 2-furylcarbinols serve as versatile building blocks in the synthesis of highly oxygenated natural products, via the oxidative conversion of 2-furylcarbinols to pyranones [52]. Pyranone and furanone derivatives, present in both plant extracts discussed herein, have been shown to possess antifungal activity [53].

Imidazoles, such as 4,5-dihydro-2-methylimidazole present in $U$. dioica extract, block ergosterol synthesis, and thereby fungal growth, by binding in the active site of 14a-demethylase enzyme [54]: the key interaction in the active site is the amidine nitrogen atom (N-3), which is believed to bind to the heme iron of the enzyme. This molecular reaction has led to an extensive use of triazoles (conazoles or imidazoles) as systemic fungicides, e.g., triadimefon, triadimenol, difenoconazole, propiconazole, cyproconazole and tebuconazole [55].

In connection with the observed synergistic behavior for the chitosan oligomers-plant extract conjugate complexes, the enhanced efficacy observed for COS-U. dioica may be tentatively explained taking into consideration changes in the unsaturated/saturated fatty acids ratio mediated by the imidazoles. On the one hand, it is well-established-on the basis of fatty acid analyses - that plasma membranes of chitosan-sensitive fungi have lower levels of unsaturated fatty acids than chitosan-resistant fungi [56]; and, on the other hand, it has been reported that imidazole antifungal agents at concentrations able to inhibit ergosterol biosynthesis $(0.1 \mu \mathrm{M})$ decrease the ratio of unsaturated to saturated fatty acids [57]. Hence, the presence of 4,5-dihydro-2-methylimidazole in the conjugate complex would increase the sensitivity of the fungal membrane to COS. This hypothesis would be 
supported by a recent study by Lo, et al. [58], who found a synergistic antifungal activity of chitosan with fluconazole against Candida spp.

With reference to the synergism observed for COS-E. arvense, it may be hypothesized that it would be related to the high content in saturated fatty acids (and particularly palmitic acid) in E. arvense extract, which would unbalance the unsaturated/saturated ratio, promoting a higher sensitivity of the fungal membrane to COS. Moreover, palmitic acid would also act as a facilitating factor of the interaction, conferring higher solubility to COS: it has been shown that amphiphilic chitosan derivatives synthesized through grafting of palmitic acid onto chitosan can dissolve in water at concentrations up to $0.35 \%$ giving colorless solutions, whereas chitosan is insoluble in water at neutral $\mathrm{pH}$ [59].

However, further research is needed to understand the exact mechanism of action and to confirm (or discard) the proposed hypotheses.

\subsection{Significance of the Reported Findings, Limitations of the Study and Further Research}

The present study deals with the potential of certain phytochemicals or basic substances to control the development of one of the most important fungal group involved in the so-called grapevine trunk diseases, and more specifically one of these mycoses, the so-called "Black Dead Arm" or "Botryosphaeria dieback" [60,61]. At least 20 taxa of this group of ascomycetous fungi have been found to cause wood symptoms in grapevine [61], although some of them have a higher incidence in young grapevine plants coming from nursery [62]. Those include taxa like N. parvum, D. seriata, L. theobromae, B. dothidea or D. mutila, most of them included in the present study. Some of these species have been associated not only with Vitis vinifera, but also with many other plant hosts [63-65], where they can induce cankers, diebacks and fruit rots. Furthermore, one of these taxa studied here, viz. N. parvum, is considered nowadays as one of the main mycoses associated with propagation material in Spain, being directly involved in a large percentage of the basal infections observed in grafted plants (from their natural infection in rootstock mother fields [62]) and being ultimately responsible for the failure of young grafted plants, $2-5$ years after their plantation. Moreover, this group of Botryosphaeriaceae species represents a potential threat to numerous crops in the Mediterranean environment, being linked to woody species that usually share habitat and bioclimatic conditions in large areas of the Mediterranean basin. Taking into consideration that in recent years there has been a drastic reduction in the number of legal active ingredients available for the treatment of these wood pathologies (current legislation recommends the universal adoption of the use of alternative methods and substances for disease control), the testing and evaluation of the protective capacities of certain simple compounds or phytochemicals of natural origin constitute a promising approach for the integrated management of this type of crops.

One clear limiting factor found in the in planta control bioassay deals with the fact that, although the vine plants were artificially infected with two pathogens of economic importance and relevance in the nursery, $N$. parvum and D. seriata, these were acquired with a significant baseline level of pre-existing pathologies in the commercial material. Thus, a first phytopathological analysis of some plants that did not sprout in the first days of the trial revealed the presence of previous wood pathologies such as vascular rot present both above the grafting point and in the environment of the root crown, and attributed to species such as Ilyonectria liriodendri, Dactylonectria macrodidyma, Rhizoctonia solani or N. parvum itself. Later and at the end of the trial, the processing of the plants that completed the entire bioassay evidenced the presence of these previous pathologies in a large percentage of them. Due to this and related to a second limiting factor in our investigation that had to do with the lack of correlation between foliar symptoms and vascular symptoms, some of the control plants of the trial exhibited symptoms (intra and inter-nerval foliar necrosis or decay of young shoots) not expected based on the absence of pathogenic inoculation. Other aspects susceptible to improvement would be associated with the dispersion medium (calcium alginate) chosen for the in planta assays, that -due to the type of polymerization reaction required for the formulation of the hydrogel beads- 
restricts the amount of active ingredient in the bioactive solution that can be incorporated to the matrix to $<20 \%$. Furthermore, subsequent experimental designs for testing the germicidal potential of these and other bioactive compounds should include different genotypes for each tested pathogen, to take into account the presumed dose/response variability when establishing sensitivity profiles for each species [66].

Given the speed at which the different fungicidal substances of chemical origin are being banned or withdrawn from their use against this type of wood pathologies, research on the potentialities offered by a wide range of alternative products is increasingly urgent and necessary. All these investigations to be carried out in the coming years must necessarily be based on the discovery, optimization and commercialization of a series of products and formulations based either on the use of substances of natural origin, alone or in combinations of several of them, or on antagonistic microbial agents, all in combination with a less intensive and stressful management of the crop.

\section{Conclusions}

The antifungal activity of the phytochemicals identified in the extracts of E. arvense and $U$. dioica, which may be referred to both their shared constituents (carbinols and other building blocks) and their specific phytochemicals (saturated fatty acids in the case of E. arvense and imidazoles in the case of $U$. dioica), was found to be modest in the absence of chitosan oligomers. Nonetheless, for the conjugate complexes of COS with the extracts of the two plants, a clear synergistic behavior was observed, both in vitro-against eight Botryosphaeriaceae fungi, with $\mathrm{EC}_{90}$ values in the $208-999 \mu \mathrm{g} / \mathrm{mL}$ range-and in vivo-with statistically significant differences in the vascular necroses caused by N. parvum and D. seriata in artificially inoculated grapevine plants. Such synergism may be ascribed to the contribution of saturated fatty acids to an enhanced sensitivity of the fungal membrane to chitosan, either directly - in the case of E. arvense extract-or mediated by imidazoles-in the case of $U$. dioica. Even though larger scale field trials are needed to further confirm the results presented herein, a combined use of these basic substances may be put forward as a promising treatment against GTDs either in organic Viticulture or as a substitute for treatments based on chemical synthesis fungicides in conventional management.

Supplementary Materials: The following are available online at https://www.mdpi.com/article/10 .3390 /agronomy11050976/s1, Table S1: Repetitions for each of the plant/treatment combinations in the greenhouse bioassay. Each grafted plant was inoculated at two sites below grafting point; Table S2: GCMS analysis of E. arvense aqueous extract; Table S3. GC-MS analysis of $U$. dioica aqueous extract; Table S4: Examples of application of E. arvense and $U$. dioica extracts against phytopathogenic fungi reported in the literature; Table S5: In vitro $\mathrm{EC}_{50}$ sensitivity values of some Botryosphaeriaceae species to technical-grade fungicides; . FTIR spectra of COS, E. arvense and $U$. dioica extract and COS-E. arvense and COS-U. dioica conjugate complexes; Figure S2. Chemical structures of phytochemicals with potential antifungal activity identified by GC-MS in E. arvense and U. dioica aqueous extracts; Figure S3. Growth inhibition for the eight Botryosphaeriaceae species under study with the chitosan oligomers (COS) treatment; Figure S4. Growth inhibition for the eight Botryosphaeriaceae species under study with the COS-E. arvense extract conjugate complex treatment; Figure S5. Growth inhibition for the eight Botryosphaeriaceae species under study with the COS-U. dioica extract conjugate complex treatment.

Author Contributions: Conceptualization, J.M.-G., P.M.-R. and V.G.-G.; methodology, J.M.-G., J.C.-G. and V.G.-G.; validation, J.C.-G., V.G.-G. and P.M.-R.; formal analysis, J.C.-G., V.G.-G. and P.M.-R.; investigation, L.B.-D., N.L.-L., V.G.-G., J.C.-G., J.M.-G., E.S.-H. and P.M.-R.; resources, J.M.-G. and P.M.-R.; data curation, J.C.-G.; writing-original draft preparation, L.B.-D., N.L.-L., V.G.-G., J.C.-G., J.M.-G., E.S.-H. and P.M.-R.; writing-review and editing, V.G.-G. and P.M.-R.; visualization, L.B.-D. and N.L-L.; supervision, V.G.-G. and P.M.-R.; project administration, V.G.-G., J.M.-G. and P.M.-R.; funding acquisition, J.M.-G. and P.M.-R. All authors have read and agreed to the published version of the manuscript. 
Funding: This research was funded by Junta de Castilla y León under project VA258P18, with FEDER co-funding; by Cátedra Agrobank under "IV Convocatoria de Ayudas de la Cátedra AgroBank para la transferencia del conocimiento al sector agroalimentario" program; and by Fundación IbercajaUniversidad de Zaragoza under "Convocatoria Fundación Ibercaja-Universidad de Zaragoza de proyectos de investigación, desarrollo e innovación para jóvenes investigadores” program.

Institutional Review Board Statement: Not applicable.

Informed Consent Statement: Not applicable.

Data Availability Statement: The data presented in this study are available on request from the corresponding author. The data are not publicly available due to their relevance to be part of an ongoing Ph.D. Thesis.

Acknowledgments: V.G.-G thanks C. Julián (Plant Protection Unit, CITA) for her technical assistance. The authors gratefully acknowledge the support of Pilar Blasco and Pablo Candela at the Servicios Técnicos de Investigación, Universidad de Alicante, for conducting the GC-MS analyses.

Conflicts of Interest: The authors declare no conflict of interest. The funders had no role in the design of the study; in the collection, analyses, or interpretation of data; in the writing of the manuscript, or in the decision to publish the results.

\section{References}

1. Damalas, C.A.; Koutroubas, S.D. Botanical Pesticides for Eco-Friendly Pest Management. In Pesticides in Crop Production; Srivastava, P.K., Singh, V.P., Singh, A., Tripathi, D.K.S., Samiksha, Prasad,, S.M., Chauhan, D.K., Eds.; Wiley: Chichester, UK, 2020; pp. 181-193.

2. Marrone, P.G. Pesticidal natural products—Status and future potential. Pest Manag. Sci. 2019. [CrossRef] [PubMed]

3. Marchand, P.A. Basic Substances under EU Pesticide Regulation: An Opportunity for Organic Production? Org. Farming 2017, 3. [CrossRef]

4. Li, K.; Xing, R.; Liu, S.; Li, P. Chitin and Chitosan Fragments Responsible for Plant Elicitor and Growth Stimulator. J. Agric. Food Chem. 2020, 68, 12203-12211. [CrossRef]

5. Ma, Z.; Garrido-Maestu, A.; Jeong, K.C. Application, mode of action, and in vivo activity of chitosan and its micro- and nanoparticles as antimicrobial agents: A review. Carbohydr. Polym. 2017, 176, 257-265. [CrossRef] [PubMed]

6. Patova, O.A.; Smirnov, V.V.; Golovchenko, V.V.; Vityazev, F.V.; Shashkov, A.S.; Popov, S.V. Structural, rheological and antioxidant properties of pectins from Equisetum arvense L. and Equisetum sylvaticum L. Carbohydr. Polym. 2019, 209, 239-249. [CrossRef]

7. Francescato, L.N.; Debenedetti, S.L.; Schwanz, T.G.; Bassani, V.L.; Henriques, A.T. Identification of phenolic compounds in Equisetum giganteum by LC-ESI-MS/MS and a new approach to total flavonoid quantification. Talanta 2013, 105, $192-203$. [CrossRef]

8. Stajner, D.; Popović, B.M.; Čanadanovicć-Brunet, J.; Anacčkov, G. Exploring Equisetum arvense L., Equisetum ramosissimum L. and Equisetum telmateia L. as sources of natural antioxidants. Phytother. Res. 2009, 23, 546-550. [CrossRef] [PubMed]

9. Committee on Herbal Medicinal Products. European Union Herbal Monograph on Equisetum arvense L., Herba. EMA/HMPC/278091/2015. Available online: https:/ / www.ema.europa.eu/en/medicines/herbal/equiseti-herba (accessed on 12 May 2021).

10. Milovanović, V.; Radulović, N.; Todorović, Z.; Stanković, M.; Stojanović, G. Antioxidant, Antimicrobial and Genotoxicity Screening of Hydro-alcoholic Extracts of Five Serbian Equisetum Species. Plant Foods Hum. Nutr. 2007, 62, 113-119. [CrossRef] [PubMed]

11. Mimica-Dukic, N.; Simin, N.; Cvejic, J.; Jovin, E.; Orcic, D.; Bozin, B. Phenolic Compounds in Field Horsetail (Equisetum arvense L.) as Natural Antioxidants. Molecules 2008, 13, 1455-1464. [CrossRef]

12. EFSA (European Food Safety Authority). Technical report on the outcome of the consultation with Member States and EFSA on the basic substance application for approval of Equisetum arvense L. for the extension of use in plant protection against fungal diseases on horticulture and vegetable crops. Efsa Support. Publ. 2020, 17, 42. [CrossRef]

13. EFSA (European Food Safety Authority). Technical report on the outcome of the consultation with Member States and EFSA on the basic substance applications for Urtica spp. for use in plant protection as insecticide, acaricide and fungicide. Efsa Support. Publ. 2016, 13. [CrossRef]

14. Mukhtar Ahmed, K.B.; Khan, M.M.A.; Siddiqui, H.; Jahan, A. Chitosan and its oligosaccharides, a promising option for sustainable crop production-A review. Carbohydr. Polym. 2020, 227. [CrossRef] [PubMed]

15. Radulovic, N.; Stojanovic, G.; Palic, R. Composition and antimicrobial activity of Equisetum arvense L. essential oil. Phytother. Res. 2006, 20, 85-88. [CrossRef]

16. Čanadanović-Brunet, J.M.; Ćetković, G.S.; Djilas, S.M.; Tumbas, V.T.; Savatović, S.S.; Mandić, A.I.; Markov, S.L.; Cvetković, D.D. Radical scavenging and antimicrobial activity of horsetail (Equisetum arvense L.) extracts. Int. J. Food Sci. Technol. 2009, 44, 269-278. [CrossRef] 
17. Nagai, T.; Myoda, T.; Nagashima, T. Antioxidative activities of water extract and ethanol extract from field horsetail (tsukushi) Equisetum arvense L. Food Chem. 2005, 91, 389-394. [CrossRef]

18. Radojevic, I.D.; Stankovic, M.S.; Stefanovic, O.D.; Topuzovic, M.D.; Comic, L.R.; Ostojic, A.M. Great horsetail (Equisetum telmateia Ehrh.): Active substances content and biological effects. Excli J. 2012, 11, 59-67.

19. Rogozhin, E.A.; Tepkeeva, I.I.; Zaitsev, D.V.; Demushkin, V.P.; Smirnov, A.N. Biological activity of peptide extracts of medicinal plants against phytopathogenic fungi and oomycetes. Russ. Agric. Sci. 2011, 37, 314-317. [CrossRef]

20. Sehari, M.; Kouadria, M.; Amirat, M.; Sehari, N.; Hassani, A. Phytochemistry and antifungal activity of plant extracts from Nettle (Urtica dioica L.). Ukr. J. Ecol. 2020, 10, 1-6. [CrossRef]

21. Torun, B.; Biyik, H.H.; Ercin, Z.; Coban, E.P. Antifungal activities of Urtica dioica L., Sinapis arvensis L. and Apium graveolens Mill. leaves on Botrytis cinerea Pers. Ann. Phytomed.-Int. J. 2018, 7, 94-97. [CrossRef]

22. Romanazzi, G.; Feliziani, E.; Santini, M.; Landi, L. Effectiveness of postharvest treatment with chitosan and other resistance inducers in the control of storage decay of strawberry. Postharvest Biol. Technol. 2013, 75, 24-27. [CrossRef]

23. Hadizadeh, I.; Peivastegan, B.; Kolahi, M. Antifungal activity of nettle (Urtica dioica L.), colocynth (Citrullus colocynthis L. Schrad), oleander (Nerium oleander L.) and konar (Ziziphus spina-christi L.) extracts on plants pathogenic fungi. Pak. J. Biol. Sci. Pjbs 2009, 12, 58-63. [CrossRef]

24. Sen, S.; Yalcin, M. Activity of commercial still waters from volatile oils production against wood decay fungi. Maderas-Cienc. $Y$ Tecnol. 2010, 12, 127-133. [CrossRef]

25. Cobos, R.; Mateos, R.M.; Alvarez-Perez, J.M.; Olego, M.A.; Sevillano, S.; Gonzalez-Garcia, S.; Garzon-Jimeno, E.; Coque, J.J. Effectiveness of natural antifungal compounds in controlling infection by grapevine trunk disease pathogens through pruning wounds. Appl. Environ. Microbiol 2015, 81, 6474-6483. [CrossRef]

26. Nascimento, T.; Rego, C.; Oliveira, H. Potential use of chitosan in the control of grapevine trunk diseases. Phytopathol. Mediterr. 2007, 46, 218-224.

27. Matei, P.M.; Martín-Ramos, P.; Sánchez-Báscones, M.; Hernández-Navarro, S.; Correa-Guimaraes, A.; Navas-Gracia, L.M.; Rufino, C.A.; Ramos-Sánchez, M.C.; Martín-Gil, J. Synthesis of chitosan oligomers/propolis/silver nanoparticles composite systems and study of their activity against Diplodia seriata. Int. J. Polym. Sci. 2015, 2015, 1-11. [CrossRef]

28. La Torre, A.; Righi, L.; Iovino, V.; Battaglia, V. Evaluation of copper alternative products to control grape downy mildew in organic farming. J. Plant. Pathol. 2019, 101, 1005-1012. [CrossRef]

29. Garcia-Cela, E.; Ramos, A.J.; Sanchis, V.; Marin, S. Ochratoxigenic moulds and effectiveness of grape field antifungals in a climatic change scenario. J. Sci. Food Agric. 2012, 92, 1455-1461. [CrossRef]

30. Buzón-Durán, L.; Langa-Lomba, N.; González-García, V.; Casanova-Gascón, J.; Martín-Gil, J.; Pérez-Lebeña, E.; Martín-Ramos, P. On the applicability of chitosan oligomers-amino acid conjugate complexes as eco-friendly fungicides against grapevine trunk pathogens. Agronomy 2021, 11, 324. [CrossRef]

31. Buzón-Durán, L.; Martín-Gil, J.; Pérez-Lebeña, E.; Ruano-Rosa, D.; Revuelta, J.L.; Casanova-Gascón, J.; Ramos-Sánchez, M.C.; Martín-Ramos, P. Antifungal agents based on chitosan oligomers, $\varepsilon$-polylysine and Streptomyces spp. secondary metabolites against three Botryosphaeriaceae species. Antibiotics 2019, 8, 99. [CrossRef] [PubMed]

32. Buzón-Durán, L.; Martín-Gil, J.; Marcos-Robles, J.L.; Fombellida-Villafruela, Á.; Pérez-Lebeña, E.; Martín-Ramos, P. Antifungal Activity of Chitosan Oligomers-Amino Acid Conjugate Complexes against Fusarium culmorum in Spelt (Triticum spelta L.). Agronomy 2020, 10, 1427. [CrossRef]

33. Mondello, V.; Songy, A.; Battiston, E.; Pinto, C.; Coppin, C.; Trotel-Aziz, P.; Clement, C.; Mugnai, L.; Fontaine, F. Grapevine trunk diseases: A review of fifteen years of trials for their control with chemicals and biocontrol agents. Plant Dis. 2018, 102, 1189-1217. [CrossRef]

34. Gramaje, D.; Urbez-Torres, J.R.; Sosnowski, M.R. Managing Grapevine Trunk Diseases With Respect to Etiology and Epidemiology: Current Strategies and Future Prospects. Plant. Dis. 2018, 102, 12-39. [CrossRef]

35. Fontaine, F.; Gramaje, D.; Armengol, J.; Smart, R.; Nagy, Z.A.; Borgo, M.; Rego, C.; Corio-Costet, M.-F. Grapevine trunk diseases. A review; OIV publications:: Paris, France, 2016; p. 25.

36. Balouiri, M.; Sadiki, M.; Ibnsouda, S.K. Methods for in vitro evaluating antimicrobial activity: A review. J. Pharm. Anal. 2016, 6, 71-79. [CrossRef] [PubMed]

37. R Core Team. R: A Language and Environment for Statistical Computing; R Foundation for Statistical Computing: Vienna, Austria, 2020.

38. Luque, J.; Elena, G.; Garcia-Figueres, F.; Reyes, J.; Barrios, G.; Legorburu, F.J. Natural infections of pruning wounds by fungal trunk pathogens in mature grapevines in Catalonia (Northeast Spain). Aust. J. Grape Wine Res. 2014, 20, 134-143. [CrossRef]

39. Aroca, Á.; Gramaje, D.; Armengol, J.; García-Jiménez, J.; Raposo, R. Evaluation of the grapevine nursery propagation process as a source of Phaeoacremonium spp. and Phaeomoniella chlamydospora and occurrence of trunk disease pathogens in rootstock mother vines in Spain. Eur. J. Plant. Pathol. 2010, 126, 165-174. [CrossRef]

40. Garcia, D.; Garcia-Cela, E.; Ramos, A.J.; Sanchis, V.; Marin, S. Mould growth and mycotoxin production as affected by Equisetum arvense and Stevia rebaudiana extracts. Food Control. 2011, 22, 1378-1384. [CrossRef]

41. Garcia, D.; Ramos, A.J.; Sanchis, V.; Marin, S. Effect of Equisetum arvense and Stevia rebaudiana extracts on growth and mycotoxin production by Aspergillus flavus and Fusarium verticillioides in maize seeds as affected by water activity. Int. J. Food Microbiol. 2012, 153, 21-27. [CrossRef] [PubMed] 
42. Rusin, C.; Cavalcanti, F.R.; Lima, P.C.G.d.; Faria, C.M.D.R.; Almança, M.A.K.; Botelho, R.V. Control of the fungi Lasiodiplodia theobromae, the causal agent of dieback, in cv. syrah grapevines. Acta Sci. Agron. 2020, 43. [CrossRef]

43. Amponsah, N.T.; Jones, E.; Ridgway, H.J.; Jaspers, M.V. Evaluation of fungicides for the management of Botryosphaeria dieback diseases of grapevines. Pest. Manag. Sci. 2012, 68, 676-683. [CrossRef]

44. Kotze, C.; Van Niekerk, J.; Halleen, F.; Mostert, L.; Fourie, P. Evaluation of biocontrol agents for grapevine pruning wound protection against trunk pathogen infection. Phytopathol. Mediterr. 2011, 50, 247-263. [CrossRef]

45. Díaz, G.A.; Latorre, B.A. Efficacy of paste and liquid fungicide formulations to protect pruning wounds against pathogens associated with grapevine trunk diseases in Chile. Crop Prot. 2013, 46, 106-112. [CrossRef]

46. Liu, S.; Ruan, W.; Li, J.; Xu, H.; Wang, J.; Gao, Y.; Wang, J. Biological Control of Phytopathogenic Fungi by Fatty Acids. Mycopathologia 2008, 166, 93-102. [CrossRef] [PubMed]

47. Clitherow, K.H.; Binaljadm, T.M.; Hansen, J.; Spain, S.G.; Hatton, P.V.; Murdoch, C. Medium-Chain Fatty Acids Released from Polymeric Electrospun Patches Inhibit Candida albicans Growth and Reduce the Biofilm Viability. Acs Biomater. Sci. Eng. 2020, 6, 4087-4095. [CrossRef]

48. Pohl, C.H.; Kock, J.L.; Thibane, V.S. Antifungal free fatty acids: A review. Sci. Against Microb. Pathog. Commun. Curr. Res. Technol. Adv. 2011, 3, 61-71.

49. Altieri, C.; Cardillo, D.; Bevilacqua, A.; Sinigaglia, M. Inhibition of Aspergillus spp. and Penicillium spp. by Fatty Acids and Their Monoglycerides. J. Food Prot. 2007, 70, 1206-1212. [CrossRef]

50. Stopiglia, C.D.O.; Vieira, F.J.; Mondadori, A.G.; Oppe, T.P.; Scroferneker, M.L. In Vitro Antifungal Activity of Dihydroxyacetone Against Causative Agents of Dermatomycosis. Mycopathologia 2010, 171, 267-271. [CrossRef] [PubMed]

51. Shobana, S.; Vidhya, V.; Ramya, M. Antibacterial activity of garlic varieties (ophioscordon and sativum) on enteric pathogens. Curr. Res. J. Biol. Sci. 2009, 1, 123-126.

52. Honda, T. Investigation of Innovative Synthesis of Biologically Active Compounds on the Basis of Newly Developed Reactions. Chem. Pharm. Bull. 2012, 60, 687-705. [CrossRef] [PubMed]

53. Komai, S.-i.; Hosoe, T.; Nozawa, K.; Okada, K.; de Campos Takaki, G.M.; Fukushima, K.; Miyaji, M.; Horie, Y.; Kawai, K.-i. Antifungal activity of pyranone and furanone derivatives, isolated from Aspergillus sp. IFM51759, against Aspergillus fumigatus. Mycotoxins 2003, 53, 11-18. [CrossRef]

54. Xiao, L.; Madison, V.; Chau, A.S.; Loebenberg, D.; Palermo, R.E.; McNicholas, P.M. Three-Dimensional Models of Wild-Type and Mutated Forms of Cytochrome P450 14 $\alpha$-Sterol Demethylases from Aspergillus fumigatus and Candida albicans Provide Insights into Posaconazole Binding. Antimicrob. Agents Chemother. 2004, 48, 568-574. [CrossRef] [PubMed]

55. Agrios, G.N. Control of Plant Diseases. Plant Pathol. 2005, 293-353. [CrossRef]

56. Xing, K.; Shen, X.; Zhu, X.; Ju, X.; Miao, X.; Tian, J.; Feng, Z.; Peng, X.; Jiang, J.; Qin, S. Synthesis and in vitro antifungal efficacy of oleoyl-chitosan nanoparticles against plant pathogenic fungi. Int. J. Biol. Macromol. 2016, 82, 830-836. [CrossRef] [PubMed]

57. Georgopapadakou, N.H.; Dix, B.A.; Smith, S.A.; Freudenberger, J.; Funke, P.T. Effect of antifungal agents on lipid biosynthesis and membrane integrity in Candida albicans. Antimicrob. Agents Chemother. 1987, 31, 46-51. [CrossRef]

58. Lo, W.-H.; Deng, F.-S.; Chang, C.-J.; Lin, C.-H. Synergistic Antifungal Activity of Chitosan with Fluconazole against Candida albicans, Candida tropicalis, and Fluconazole-Resistant Strains. Molecules 2020, 25, 5114. [CrossRef] [PubMed]

59. Kolesnyk, I.; Konovalova, V.; Kharchenko, K.; Burban, A.; Kujawa, J.; Kujawski, W. Enhanced transport and antifouling properties of polyethersulfone membranes modified with $\alpha$-amylase incorporated in chitosan-based polymeric micelles. J. Membr. Sci. 2020, 595. [CrossRef]

60. Larignon, P.; Dubos, B. Le Black Dead Arm: Maladie nouvelle à ne pas confondre avec l'esca. Phytoma-La Défense Des Végétaux 2001, 538, 26-29.

61. Urbez-Torres, J.R. The status of Botryosphaeriaceae species infecting grapevines. In Phytopathologia Mediterranea; University of Florence: Florence, Italy, 2011; Volume 50, pp. 5-45.

62. Gramaje, D.; Armengol, J. Fungal Trunk Pathogens in the Grapevine Propagation Process: Potential Inoculum Sources, Detection, Identification, and Management Strategies. Plant Dis. 2011, 95, 1040-1055. [CrossRef]

63. Marsberg, A.; Kemler, M.; Jami, F.; Nagel, J.H.; Postma-Smidt, A.; Naidoo, S.; Wingfield, M.J.; Crous, P.W.; Spatafora, J.W.; Hesse, C.N.; et al. Botryosphaeria dothidea: A latent pathogen of global importance to woody plant health. Mol. Plant Pathol. 2017, 18, 477-488. [CrossRef]

64. Moral, J.; Agustí-Brisach, C.; Pérez-Rodríguez, M.; Xaviér, C.; Raya, M.C.; Rhouma, A.; Trapero, A. Identification of fungal species associated with branch dieback of olive and resistance of table cultivars to Neofusicoccum mediterraneum and Botryosphaeria dothidea. Plant Dis. 2017, 101, 306-316. [CrossRef]

65. Olmo, D.; Gramaje, D.; Armengol, J. Evaluation of fungicides to protect pruning wounds from Botryosphaeriaceae species infections on almond trees. Phytopathol. Mediterr. 2017, 56, 77-86.

66. Fan, K.; Wang, J.; Fu, L.; Li, X.; Zhang, Y.; Zhang, X.; Zhai, H.; Qu, J. Sensitivity of Botryosphaeria dothidea from apple to tebuconazole in China. Crop Prot. 2016, 87, 1-5. [CrossRef] 